Institute of $\mathbf{F}_{\text {ood and }} \mathbf{A}_{\text {gricultural }} \mathbf{S}_{\text {ciences }}$

\title{
Government Policy and Farmland Markets: Implications of the New Economy--Part $\mathbf{2}^{1}$
}

\section{Charles B. Moss and Andrew Schmitz, Editors ${ }^{2}$ \\ Introduction}

Farmland has occupied a dominant position in U.S. agricultural policy since the founding of the nation. The Homestead Act of 1862 provided a mechanism for allocating unoccupied land to farmers. The establishment of the Federal Land Bank in 1916 provided longer-term credit for the purchase of land. Programs such as the Farmer's Home Administration provided credit so that sharecroppers and beginning farmers could purchase farmland. More recently, farmland has accounted for an average of 70 percent of all agricultural assets (1950-1999). Sherrick and Barry examine the historical perspective as it pertains to contemporary Issues. The dominance of land values in the agricultural balance sheet has several implications. First, sector wealth and solvency are intricately tied to farmland prices. This link between farmland values and solvency has implications for the sector's cost of capital and its economic viability. Second, government programs may have a direct effect on farmland values. Economic theory holds that the net value of benefits generated by farm programs are bid into the value of farmland. Third, the emerging environmental agenda has dramatic consequences for farmland prices. In the post-war period, the United States has experienced rapid economic and population growth. This growth provides an alternative use for land, increasing its price in some areas. In addition, the growth in income has increased the public's demand for environmental goods that affect both the price and productivity of farmland. A conference on farmland values held in at the Waugh Auditorium at the United States Department of Agriculture, Economic Research Service on May 6, 2002, addressed several of these issues and attempted to develop the emerging set of research questions for the Twenty-First Century. Sponsors included: the Farm Foundation, Illinois Branch; USDA/CREES; USDA/NRI; Ben Hill Griffin, Jr. Chair, University of Florida; Institute of Food and Agricultural Sciences, University of Florida; USDA/ERS; Swank Chair, Ohio State University; and the USDA/Economist's Group.

The papers presented at this conference included several studies of the linkage between farmland values and government programs; however, little consensus on the impact of government policy on farmland values emerged. Schmitz and Just provided cross-country evidence that farm commodity programs directly affect farmland values through a comparison of land values within Canada and

1. This is EDIS document FE358, a publication of the Department of Food and Resource Economics, Florida Cooperative Extension Service, Institute of Food and Agricultural Sciences, University of Florida, Gainesville, FL. Published October 2002. Please visit the EDIS website at http://edis.ifas.ufl.edu

2. Charles B. Moss, Professor, and Andrew Schmitz, Ben Hill Griffin Eminent Scholar and Professor, Department of Food and Resource Economics, Florida Cooperative Extension Service, Institute of Food and Agricultural Sciences, University of Florida, Gainesville, FL. 
between Canada and the United States. However, the presentation by Gardner questions the capitalization of government payments into farmland values through a comparison of changes in farmland values across rural counties in the United States. The paper by Goodwin and Mishra strikes an intermediate position, concluding that farmland values are affected by government payments in the short run. However, the impact of government payments on farmland values varies by the type of payment. The presentation by Carlsberg and Furtan examines the impact of farmland ownership laws on farmland values in Saskatchewan, Canada. Their results show that farmland prices are not affected by foreign ownership laws.

A second set of papers examined the possibilities of boom/bust cycles in farmland prices. Featherstone and Moss find that these boom/bust cycles exist, but conclude that the driving forces behind these boom/bust cycles lie outside the asset fundamentals (or changes in returns to farmland and interest rates). Turvey concludes that a portion of the boom/bust cycles may be attributed to the option value that accrues by holding farmland. However, the option value alone is insufficient to explain the extreme boom/bust cyclical behavior observed in the farmland market. Two of the papers presented examine the role of transaction costs in explaining the boom/bust cycle behavior. Chavas develops a theoretical model that demonstrates how transaction costs can cause the demand for farmland to be inelastic. The inelastic portion of the demand function could then give rise to boom/bust cycles. Miller uses an empirical approach to measure the potential significance of these transaction costs. He finds that asset value movements are consistent with frictions added by transaction costs in the short and intermediate run. However, these transaction costs alone are insufficient to explain the long run boom/bust cycles observed in farmland.

A third set of papers examined the amenity values of farmland and the influence of urban growth and urban growth related policies on farmland markets. Libby and Irwin provide an overview of the amenity values of farmland and examine the extent to which policies aimed at protecting farmland and reducing urban sprawl have impacted farmland markets. In general, they find that these policies have not had a significant impact on farmland prices. Barnard, Wiebe and Breneman then focus on the effect of urban sprawl on farmland values in the United States. The study finds that 17 percent of the farmland in the United States is influenced by urbanization. This urbanization increases the market price of farmland, increasing the entry cost of new farmers and the cost of expansion for existing farmers.

This paper provides a synopsis of papers presented at the "Government Policy and Farmland Markets: Implications for the New Economy" Conference held in Washington, D.C. on May 6, 2002. Extended versions of these papers can be found in a forthcoming volume from Iowa State University Press. Also, some of the issues from the papers are summarized in EDIS publication FE342.

\section{The Economics of Farmland Values: Rent Seeking and Government Policies}

Based on regional and international comparisons between the United States and Canada, this paper concluded that government policies significantly affect land values. Comparing farmland values in Canada and the United States shows that farmland values in Saskatchewan are much lower than those in Montana, even though both regions have similar crop mixes, productivity, etc. However, the impact of government programs is evident not only across countries, but also within Canada. Comparing farmland values in Saskatchewan with those in Ontario and Quebec shows that farmland values in the Prairie region have steadily declined since the 1980s while farmland values in eastern Canada remain strong. This discrepancy may be attributable to differences in agricultural policy within Canada. Import-competing commodities dominate agriculture in the eastern provinces. These import-competing commodities receive support through supply controls while the export-oriented crops grown in the Prairie receive little (if any) direct or indirect support.

Looking beyond the political economy of commodity programs, an important question remains: Who are agricultural programs that affect farmland values intended to support? Increases in farmland 
values driven through these government programs generate wealth. This increased wealth yields two results. First, it increases the financial solvency of the sector, protecting agricultural lenders. Second, current landowners capture the wealth benefits. However, it also increases the cost to young farmers who must buy these future benefits. Further, the implications for allocation of benefits between farmers and absentee landowners are uncertain.

Authors: Andrew Schmitz (University of Florida) and Richard Just (University of Maryland)

\section{Farmland Markets: Historical Context and Contemporary Issues}

Farmland markets in the United States are analyzed with historical information summarizing farm real estate values, farm structure and control arrangements, turnover rates, specialized institutions in agriculture, the role of government payments, and evidence of market frictions. The favorable performance of agricultural real estate as an asset class is examined vis-a-vis other investment alternatives and relative to its specific risks. The paper also discusses contemporary issues that deserve attention in future research, and in debate about the effects of government policy on farmland markets.

Important features of farmland include the relative dominance on the balance sheet of U.S. agriculture (approximately 75 percent of the total assets), the relatively low aggregate leverage of the sector, and low share of debt supporting farmland. The historic returns to farmland have been dominated by capital gains rather than current income. The importance of leasing markets is indicated by the fact that roughly 45 percent of all land farmed in the United States operated under a leasing arrangement. Leasing patterns and practices continue to evolve, as evidenced by changing ownership and leasing patterns. Evidence and implications of low farmland turnover rates (averaging less than one percent of total farmland in Illinois for example) are discussed. The favorable performance of farmland investments relative to other asset classes and across different risk classes is indicated by low correlations with returns to other asset classes.
The paper also discusses the magnitude and general characteristics of government payments in agriculture and suggests future roles that the government may serve to enhance the efficiency of farmland ownership and leasing markets. The roles of non-farm demand for farmland, changing leasing patterns, government policy focuses, changing property rights issues, and issues related to the urban/rural interface are argued to be of particular importance in understanding and forming appropriate polices affecting farmland in the future.

Authors: Bruce J. Sherrick (University of Illinois) and Peter J. Barry (University of Illinois)

\section{Capital Markets, Land Values, and Boom-Bust Cycles}

Historically, farmland values in the United States have been subject to periodic boom/bust cycles where they systematically rise above or fall below their long-run equilibria. This may result in periods of financial volatility within the sector. The economic boom period of the late 1970s left the sector with high levels of real estate debt that raised difficulties when the boom subsided. Similarly, the bust period of the late 1980s may have resulted in efficient producers leaving the sector as their credit reserves evaporated. Given the financial difficulties that arise out of either boom or bust periods, this study examined historical evidence of these cycles, focusing on whether the cycles can be explained by financial fundamentals within the sector.

The study examined the interaction between farmland values, returns to farmland, and interest rates for four states: Florida, Kansas, Illinois, and Indiana. The results indicate that both farmland values and interest rates are driven by long-run expectations (changes in these values appear to be permanent rather than transitory) while returns to farmland contained significant short-run (or transitory) variability. In addition, the long run or persistence in farmland price movements explain the boom/bust cycles for farmland. The short-run volatility in returns to farmland is consistent with the nature of agricultural production. Weather (both in the United States and abroad) can significantly affect output and prices in any given year. However, the 
results indicate that these short-run fluctuations are not the driving force behind these boom/bust cycles.

Authors: Allen M. Featherstone (Kansas State University) and Charles B. Moss (University of Florida)

\section{Hysteresis and the Value of Farmland: Real-Options Approach to Farmland Evaluation}

Most studies of farmland values have used the present value formulation for asset pricing either directly or indirectly. Within this framework, the value of farmland is determined by the present value of future cash flows arising from the purchase of the asset. If the present value of future cash flows exceeds the market value of the asset, investors will increase their bids on the assets (so the market value of farmland increases). Alternatively, if the market value of the asset exceeds the present value of future cash flows, buyers reduce their bids (so the market value of farmland falls). This study departs from the present value formulation by examining the option value implicit in the ownership of farmland (its real-option value). Specifically, the decision to sell an asset is seldom a now-or-never decision. One may decide to hold the asset for another year in the hope that the price of the asset will increase. In this way, a portion of the price of an asset can be viewed as an option value. The study then examined whether these changes in option values help to explain the behavior of farmland values over time.

In general, the study finds that there is a positive option value associated with holding farmland, using Ontario farmland values between 1971 and 1998. The option value adds on average $\$ 364.41$ per acre to farmland values over time and represents on average 29 percent of the total value of farmland. However, including the option value alone does not account for the boom/bust cycle in farmland values.

Author: Calum G. Turvey (University of Guelph)

\section{Transaction Costs and Farmland Value}

One critical assumption of traditional asset pricing models is that transactions are costless. Obviously, real estate transactions are not costless, but may entail significant relative cost, especially when the parcel size is small. This paper demonstrates how transaction costs affect land markets. Specifically, the paper shows how the presence of transaction costs increases the volatility of land prices in the short run by making both the short-run supply and demand for farmland perfectly inelastic for small changes in farmland prices. The fixity introduced by these transaction costs increases with homogeneity within the farm household. Thus, if the farms become more similar, the area of price rigidity increases.

These theoretical results indicate that transaction costs add to the common conjecture that farmland markets are thin (at any given time few land parcels are available for sale, which increases the observed price instability within an asset market). This suggests that in thin markets (i.e., markets dominated by homogeneous farm households) the market price for farmland is heavily dependent on household-specific shocks. Further, one dynamic consequence of the model is that positive search costs lead to more unstable markets by raising the transaction costs. In addition, transaction costs may lead to increased market segmentation.

Author: Jean-Paul Chavas (University of Wisconsin)

\section{Further Results on lowa Farmland Values and Transaction Costs}

Building on the transaction cost framework presented by Chavas, this paper examines the empirical evidence supporting the role of transaction costs. If transaction costs explain the volatility in farmland values (boom/bust behavior as discussed in Featherstone and Moss), then farmland value changes outside the range of observed transaction costs should follow financial fundamentals within the sector.

While asset movements within a range predicted by transaction costs may not be affected by changes in 
returns to farmland and interest rates, any volatility outside the range predicted by transaction costs must be consistent with those changes.

This study examines the volatility in farmland prices, greater than transaction cost, in the short and long run for farmland prices in Iowa. The results suggest that, after accounting for transaction costs, the changes in farmland prices plus returns are explained by financial fundamentals. Thus, transaction costs account for the price volatility in the short run. However, extending the analysis to the long run by using a constant discount rate present value formulation, excess volatility remains in farmland markets for holding periods greater than 10 years. Thus, transaction costs explain the increased volatility in the short and intermediate run, but changes in farmland prices over longer periods exceed the observed transaction costs.

\section{Author: Douglas Miller (Purdue University)}

\section{Effect of Urban Influence (Sprawl) on Farmland Values}

In recent decades, urban development has pushed outward from city centers, in a form (often characterized as sprawl) that increasingly intersperses urban activities with farm activities in traditionally rural areas. Although the official "urbanized area" accounts for only about three percent of the U.S. land base, results from this study indicate that urban influence now affects about 17 percent of the Nation's agricultural land. When urban influence spreads to rural areas, it affects farms in a number of ways, the most observable of which may be the inevitable rise of the market value of potentially developable farmland above its agricultural production value. Using data from national USDA surveys in conjunction with a Geographic Information system (GIS), this paper examined two aspects of urbanization: How large is the urban-influenced zone in terms of farmland acres? And how much of farmland value is accounted for by urban influence? The analysis (focused on 20 Land Resource Regions) also examines changes in the real extent of urban influence over the 1994-2001 period and differences in the rate of change in value for farmland subject to varying degrees of urban influence. The effects of non-farm development on agriculture in the urban-influence zone, including the "von Thuenen" effect, are discussed. The implications that rapidly changing communications and transportation technologies hold for the amount and value of urban-influenced farmland are also explored.

Authors: Charles H. Barnard, Keith Wiebe, and Vince Breneman (United States Department of Agriculture)

\section{Rural Amenities and Farmland Values}

Farmland value is a reflection of the returns to the various services that flow from that land. Among the attributes that contribute value to land are certain amenity characteristics. Some of the amenity services of farmland are exclusive and rival, captured by the owner and priced for purchase by consumers. Other amenities are not priced in a land market; they are public goods that are to some extent nonexclusive and/or non-rival in consumption and whose values are not reflected in market price.

Many people other than owners perceive utility from the way that land is used. These non-owners express their preferences through the policy process, and institutional changes may alter the opportunities available to the owner in the interest of retaining certain amenity services. The owner of farmland retains most of the discretion in how the land will be used, but non-owners gain rights as well through the policy process. Some of that policy intervention is to protect the general health and safety of the population, as with requirements that farm-generated water pollution be reduced, endangered species habitat be protected, or pesticides be stored and handled properly. Other policy actions seek to alter the owner's choices to implement some notion of countryside scenery or secure such eco-system services as nutrient recycling, groundwater recharge or habitat protection. The instruments of policy that reassign land use rights in the interest of amenity services include regulation, taxation and other monetary incentives, and outright purchase of the land. 
This paper reviews the range of amenity services of farmland, both those captured in market price of farmland and those that are not reflected in market price. Included in the former are on-farm recreation, hunting rights, farmers markets, tours, and other farm seminars for which people will pay a price. Examples of the latter are eco-system services and the "heritage value" of farms. Evidence of the market and non-market economic values of these amenities is then reviewed. Finally, the paper discusses the effects of amenity-securing policies on farmland value and the success of such policies in achieving the often-stated goals of farmland retention and abatement of urban sprawl.

Authors: Larry Libby and Elena Irwin (Ohio State University)

\section{U.S. Commodity Policies and Land Prices}

Common consensus in the agricultural economics literature is that the economic rents (returns from government programs) are bid into the most fixed factor of production, typically assumed to be farmland. This presentation examined whether this assumption is supported by the data. Specifically, this research examines whether farmland prices respond to government programs in the long run. To empirically investigate this response, the research examined the change in land values for 80 rural counties across the United States from 1950 to 2000. This change in land value was regressed on several factors, including the significance of program crops and the total level of commodity payments in 1992. Overall these program variables were found to be statistically insignificant in explaining changes in farmland values. Reasons include the fact that government payments only occur when commodity prices are low. Alternatively, the results may suggest that farmers view the level of payments as transitory (similar to the findings of in the previous presentation by Featherstone and Moss). Regardless of the reason, the presentation suggests that the linkage between program payments and farmland values should be reinvestigated with greater attention paid to long run interactions.
Author: Bruce Gardner (University of Maryland)

\section{Foreign Ownership and Farmland Values}

Restrictions on the foreign ownership of farmland by non-residents are common occurrences. Such restrictions were imposed governmentally on Saskatchewan, Canada by the edicts of the Saskatchewan Farm Security Act (FSA) established in 1974. Some observers blamed the FSA for depressing provincial land values. This study empirically examines the impact of such restrictions on farmland values in Saskatchewan and the potential effect of these restrictions on rural communities (migration). The empirical model examines whether the ratio of farmland values in Saskatchewan divided by the farmland values in Alberta responds to the passage of foreign ownership restrictions. The estimated coefficients are not statistically significant, implying that the FSA did not have an adverse effect on farmland values in Saskatchewan. Extending the framework, the research then examined whether these laws affected migration from the province. Again, comparing Saskatchewan with Alberta (but focusing on adjacent rural municipalities in each province), the empirical estimates suggest that the FSA did not significantly affect migration.

Authors: Jared Carlsberg (University of Manitoba) and W. Hartley Furtan (University of Saskatchewan)

\section{Explaining Regional Differences in the Capitalization of Policy Benefits into Agricultural Land Values}

This study, like that of Gardner, examines whether farmland values are affected by farm program payments. However, while most research examining the relationship between policy benefits and land values have been done at an aggregate (e.g., county, state, or county) level, this analysis pursues a somewhat different approach in that farm-level data are evaluated. In particular, the study utilizes farm-level data from the Agricultural Resource Management Survey (ARMS) project. An initial evaluation of these data reveals that differences in the ratio of farm program payments to land values (a 
rough indicator of the extent to which payments affect land values) vary widely across states, with the largest values appearing in sparsely populated states with high levels of production of program crops. This is certainly expected in that there are many determinants of expected future rents other than agricultural policy support. In particular, the extent to which opportunities for non-agricultural uses of land exist will be relevant to the determination of land values and the extent to which current program benefits are reflected in land values.

The empirical results indicate that different agricultural programs have different effects on farmland values. In general, loan deficiency payments directly affect farmland values, while long-term payments have relatively little impact.

Authors: Barry K. Goodwin (Ohio State University) and Ashok K. Mishra (United States Department of Agriculture)

\section{Research Papers}

The Economics of Farmland Values: Rent Seeking and Government Policy - Andrew Schmitz (University of Florida) and Richard Just (University of Maryland)

Historical Perspective on Farmland Markets: Context and Contemporary Issues- Bruce Sherrick (University of Illinois) and Peter Barry (University of Illinois)

Capital Markets, Land Values, and Boom-Bust Cycles - Allen Featherstone (Kansas State University) and Charles B. Moss (University of Florida)

Hysteresis and the Value of Farmland: A Real-Options Approach to Farmland Valuation Calum Turvey (University of Guelph)

Transaction Costs and Farmland Values Jean-Paul Chavas (University of Wisconsin)

Further Results on Iowa Farmland Values and Transaction Costs - Douglas Miller (Purdue University)
Effect of Urban Influences (Sprawl) and Farmland Values - Charles Barnard (United States Department of Agriculture), Keith Wiebe (U.S. Department of Agriculture), and Vince Breneman (United States Department of Agriculture)

Rural Amenities and Farmland Values - Larry Libby (Ohio State University) and Elena Irwin (Ohio State University)

U.S. Commodity Policies and Land Prices Bruce Gardner (University of Maryland)

Foreign Ownership and Farmland Values Hartley Furtan (University of Saskatchewan) and Jared Carlberg (University of Manitoba)

Explaining Regional Differences in the Capitalization of Policy Benefits into Agricultural Land Values - Barry K. Goodwin (Ohio State University), Ashok Mishra (U.S. Department of Agriculture), and Francois N. Ortalo-Mangné (London School of Economics).

These are forthcoming in Government Policy and Farmland Markets: Implications for the New Economy, edited by Charles B. Moss and Andrew Schmitz, State University Press, 2003. 